Volume 3 Issue 9 (September 2021) PP. 143-154

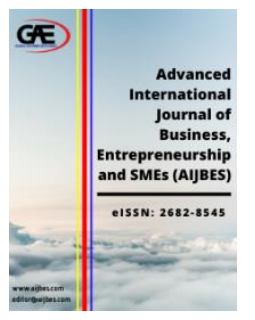

\author{
ADVANCED INTERNATIONAL JOURNAL OF \\ BUSINESS, ENTREPRENEURSHIP AND SMES \\ (AIJBES) \\ www.aijbes.com
}

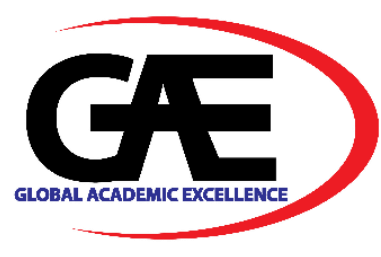

\title{
THE EFFECTIVENESS OF PRODUCT PLACEMENT ON YOUTUBE CONTENT VIDEO TOWARD CONSUMER PURCHASE DECISION IN INDONESIA
}

Milyana Rahayu ${ }^{1}$

1 School of Business and Management, Institut Teknologi Bandung

Email: milyana_rahayu@sbm-itb.ac.id

\section{Article Info:}

Article history:

Received date: 14.06 .2021

Revised date: 04.07.2021

Accepted date: 04.08.2021

Published date: 02.09.2021

\section{To cite this document:}

Rahayu, M. (2021). The Effectiveness of Product Placement on YouTube Content Video toward Consumer Purchase Decision in Indonesia. Advanced International Journal of Business, Entrepreneurship and SMEs, 3 (9), 143-154.

DOI: 10.35631/AIJBES.39011.

This work is licensed under $\underline{\mathrm{CC} B Y} 4.0$

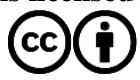

\begin{abstract}
:
Nowadays, almost everyone knows YouTube as one of the world's most popular social media platforms. The usage of YouTube is not only a place to share videos but also as a medium for information, aid learning, and even as a commercial medium for business. With the increasing popularity of YouTube, marketers have discovered a new way of integrating their product into online videos namely YouTube product placement. An example of popular product placement is by one of the healthy instant noodle brands from Indonesia who collaborates with well-known Indonesian YouTube influencers. However, even though YouTube has already existed and been popular for a long time, there is still a few research that discusses product placement in YouTube content. Therefore, this research is important to find out whether a YouTube content with a product placement delivered by a YouTube influencer will be effective in influencing the viewers' purchase decisions or not. This research will be used a quantitative approach to collect the data by conducting the survey method. The researcher uses descriptive statistics and PLS-SEM to analyze the data. The results indicate that product placement on YouTube content video has a positive influence on consumer purchase decisions in Indonesia.
\end{abstract}

\section{Keywords:}

Content, Indonesia, Noodle, Purchase Decision, Product Placement, YouTube Influencer, YouTube

\section{Introduction}

Nowadays, almost everyone knows YouTube as one of the world's most popular social media platforms. YouTube is a multimedia sharing service that allows users to watch content posted by other users and upload videos of their own (Christensson, 2009). In Indonesia, YouTube is Copyright (C) GLOBAL ACADEMIC EXCELLENCE (M) SDN BHD - All rights reserved 
Volume 3 Issue 9 (September 2021) PP. 143-154

DOI 10.35631/AIJBES.39011

the most used social media platform with data showing that the penetration rate is more than $88 \%$ (Statista, 2019). This is also the impact of the widespread use of the internet in society, the use of the internet is now starting to be applied to various functions and purposes. Most people in Indonesia prefer to use YouTube as a medium of entertainment, this can be seen from the data 8 out of 10 Indonesian YouTube channels with subscribers are YouTube channels with the entertainment category (Hypeauditor, 2021). Moreover, 92 percent of YouTube users in Indonesia stated that YouTube is the first place to go if they are looking for video content (Praditya, 2018).

Due to the boost of popularity of online video content on YouTube and other social media platforms (Folkvord et al., 2019), marketers have discovered a new and remarkable way of integrating their product into online videos namely YouTube product placement. Product placement itself has the definition as a marketing strategy by placing branded products, packaging, or other trademarked goods on a film, television program, or other digital media to increase customer memory of the brand and briefly make it easier to introduce a product in a location purchase (Panda, 2004).

Based on the popularity of online video content on YouTube, product placement can also be found easily on the content of Indonesia's popular YouTube influencers (YouTubers.me, 2020). One of the examples of brands that have implemented the Product Placement strategy in the YouTube content is "Mie Lemonilo", the brand collaborates with some of the most famous YouTube channels in Indonesia such as Rans Entertainment, Baim Paula, and Ricis Official. Based on the way YouTube influencers communicate a brand, we can find out that they make a plot connection in implementing product placement, which is one of the dimensions in Tripartite Typology theory. According to Russell (1998), the plot connection dimension refers to the degree to which the brand is integrated into the plot of the story.

The plot is very important for the inclusion of product placement into content or media, this is supported by previous research which states that a good plot integration will affect the consumer's ability to remember a brand (Bressoud, Lehu, \& Cristel, 2010). Moreover, previous research also showed that product placement will affect consumer brand awareness, and this will also have an impact on consumer purchase intention (Kristanto \& Brahmana, 2016), the advantages of product placement are indeed an advantage that marketers are looking for. By having the largest share of content marketing, YouTube may become a product placement channel. YouTube has content of over one billion users producing billions of views and viewing hundreds of millions of hours of video content every day. One of the most critical aspects of YouTube is its ability to create a strong sense of community among its users (Boyd, Clarke, \& Spekman, 2014).

Marketers have become very interested in entering into advertisements or product placement deals with YouTube influencers since their phenomenon began in 2009 (Gerhards, 2019). Even though YouTube has already existed for a decade, there is still a few research that discusses product placement in YouTube content compared to product placement on other mediums such as television and film. This research is important to find out whether a YouTube content with a product placement delivered by a YouTube Influencer will be effective in influencing the viewers' purchase decisions or not. Besides that this research is also important because we will find out whether the difference in the product placement medium, which previously used television shows to become YouTube content, will be successful in influencing consumers more on their purchase decision of a product or not. Because, although previously it was said Copyright (C) GLOBAL ACADEMIC EXCELLENCE (M) SDN BHD - All rights reserved 
Volume 3 Issue 9 (September 2021) PP. 143-154

DOI 10.35631/AIJBES.39011

that product placement was widely used in television, previous research has also stated that people still believe that they were more influenced to buy a product when they see it in a commercial advertisement rather than the product placement they saw in television shows.

\section{Literature Review}

\section{Product Placement}

Product placement is a marketing strategy that places branded products, packaging, or other trademarked goods on a film, television program, or other digital media to increase customer memory of the brand and briefly make it easier to introduce a product in a location purchase (Panda, 2004). Depending on whether products or brands are illustrated, product placement can also be called brand placement (Karrh, 1998).

\section{YouTube}

YouTube is a multimedia sharing service that allows users to watch content posted by other users and upload videos of their own (Christensson, 2009). YouTube is one of the social media networks with the largest social effects, and it is also stated to be the most valuable social network (IAB, 2015). YouTube has proven itself to be a popular platform with evidence showing that $79 \%$ of internet users claim that they have a YouTube account (Datareportal, 2019). Nowadays, YouTube is not only a place for sharing videos, but also as a platform for information, learning support, and even as a business medium. Statistics show that $62 \%$ of companies use YouTube as a platform to post their content (Buffer, 2019) as evidence.

\section{Branded Content}

Based on a study conducted by IPG Media Lab and Google (2015), branded content is described as content that lives on its own, created by and for a brand, as opposed to content produced by someone else to which the brand is committed. Moreover, the Branded Content Marketing Association interprets the concept of branded content from a comprehensive and managerial viewpoint and describes it as any content associated with a brand in the eye of the audience (Canter et al., 2013). In addition, based on previous research, it has been concluded that content marketing can create value through the providing of informative and/or entertaining information about a brand (Lou et al., 2019). Therefore, this research will examine further the influence of the informative value and entertainment value of a branded content.

\section{Brand Experience}

Previous research has shown that sensations, emotions, cognitions, and behavioral reactions that arise due to brand-related stimuli that are part of design and brand identity, packaging, communication, and the environment are conceptualizations of brand experience (Brakus et al., 2009). Brand-related stimuli such as product design, identity, packaging, marketing communications, advertising, and distribution locations are exposed to consumers when they search for, buy and consume brands and can consequently influence consumer brand choices (Ramaseshan \& Stein, 2014).

\section{Entertainment Value}

McQuail (1983) explains that advertising entertainment describes media users' entertainment needs and illustrates advertising content's function in entertaining consumers (Lou et al., 2019). Moreover, based on the previous research, it stated that by allowing the audience to exchange information, experiences, music and video clips, and so on with their social connections (Kim 
Volume 3 Issue 9 (September 2021) PP. 143-154 DOI 10.35631/AIJBES.39011

et al., 2011), there will be an entertainment value that is said to lie in the ability to meet the audience's needs for emotional release, distraction, and pleasure (Muntinga et al., 2011).

\section{Informative Value}

Ducoffe (1996) states that the informativeness of advertising refers to the ability of advertising to provide information about alternative product information. As a source of information that is needed and pursued on time, advertising that attracts customer attention may lead consumers to certain producers and products (Pollay \& Mittal, 1993). Therefore, in this research, the researcher wanted to know the effect of informativeness on YouTube content.

\section{Source Credibility}

Previous research has stated that Message source credibility has the meaning of how much the message receiver believes in the sender (Wu \& Wang, 2011). Moreover, the credibility point in a message is also an important factor that can affect the effectiveness of persuasion (Hovland \& Weiss, 1951).

\section{Brand Image}

Brand image is created by a group of features of an extraordinary nature, specific to a given brand that causes its distinction, while at the same time ensuring the desired recognition of the consumer (Świtała et al., 2018). Simultaneously from other research has pointed out that the image of a brand is a perception made as a result of some factors (e.g. associations associated with a specific brand name, buying experience, a certain prestige of the business, the type and scale of advertisement, promotion, etc.), which means that from the point of view of several recipients, this is a dynamic, inhomogeneous one a complex one (Pars \& Gulsel, 2011).

\section{Brand Attitude}

Brand attitude could be described as a network of integrated perceptions and long-lasting opinions about a brand: an overall brand assessment (Eagly \& Chaiken, 1993; Keller, 1993). Also, research has shown that attitudes can shift over time through a variety of marketing stimuli (Keller \& Lehmann, 2006) and the behavioral relationship is subject to various operational effects (Park \& MacInnis, 2006).

\section{Brand Loyalty}

Based on previous research, brand loyalty means the attachment a customer has to a brand (Aaker, 1991), which will increase customer repurchase behavior and brand competitiveness (Matzler et al., 2008). In addition, Jacoby and Kyner (1973) describe loyalty as a response to biased behavior carried out by decision-making units concerning one or more alternative brands from a set of brands and as a function of the psychological process then expressed over time.

\section{Trust}

Trust in brands has a similar sense to support for companies and is an important factor in the relationship between customers and brands (Fournier, 1998). The previous researcher already proposed that brand trust is similar to interpersonal trust so that it is a "feeling of security held by the consumer that the brand will meet their consumption expectations" (Delgado \& Munuera, 2001). 


\section{Purchase Intention}

Purchase intention is the consumer's willingness to purchase a product or service. Many factors may influence the intention of the consumer when choosing the product, and the final decision depends on the intention of the consumer with broad external factors (Keller, 2001). Based on previous studies, it is stated that consumer knowledge of the product plays an important role in the decision to purchase the product (Satish \& Peter, 2004).

\section{Purchase Decision}

A variety of customer decisions are most likely to result from the combination of previous buying experience, marketing programs, and non-commercial information sources (Schiffman \& Kanuk, 2007). Past literature has pointed out that customers typically tend to minimize risk in their buying decisions (Chaipradermsak, 2007).

\section{Methodology}

The first step that performed to carry out the study by the researcher is problem identification. After the problem was identified, a variety of forms of literature related to the issues were also reviewed to support the study. Moreover, a quantitative approach will be used to collect the data by conducting the survey method. A survey method is used to determine the behavior of consumers or viewers who are influenced by product placement on YouTube content. Surveys can also be carried out using a variety of techniques, this time the survey method used is through a questionnaire. The population of this research is people that are actively using YouTube who are domiciled in Indonesia. This research is limited to 3 YouTube channel videos with people and blog categories from local YouTube influencers (Rans Entertainment, Baim Paula, and Ricis Official) who are included in the 10 Indonesian YouTube channels with the most subscribers (minimum 14.3M subscribers). The product placement variance is also limited to the brands of food products because it is the kind of product placement that is more often found in their content. Before filling out the online survey, the participants are asked to watch a product placement content video (which is limited to Mie Lemonilo products) posted by the local YouTube channels (Rans Entertainment, Baim Paula, Ricis Official). The participants can provide information about their perception and experience after watching the product placement content video that will provide insights into this research. The sample size applied in this research refers to the previous study which stated that the minimum sample size used for the marketing study is 200 samples (Malhotra et al., 2016). Therefore, this research's sample size is a minimum of 300 samples divided into 100 samples for each YouTube channel. In this study, the researcher will use descriptive statistics and PLS-SEM to analyze the data. After the data were analyzed, the next step is the data will be discussed to reach a conclusion and recommendations.

\section{Discussion and Analysis}

Based on the discussion, this study can conclude that there are several variables that influence consumer purchase decisions. The independent variables are Brand Experience, Entertainment Value, Informative Value, and Source Credibility. The findings of this research can be used to analyze the effect of factors in product placement on YouTube content on consumer purchase decisions and to develop a product placement strategy in YouTube content that is effective in influencing consumer purchase decisions. The conceptual framework for this study depicted in figure 1. 
Volume 3 Issue 9 (September 2021) PP. 143-154

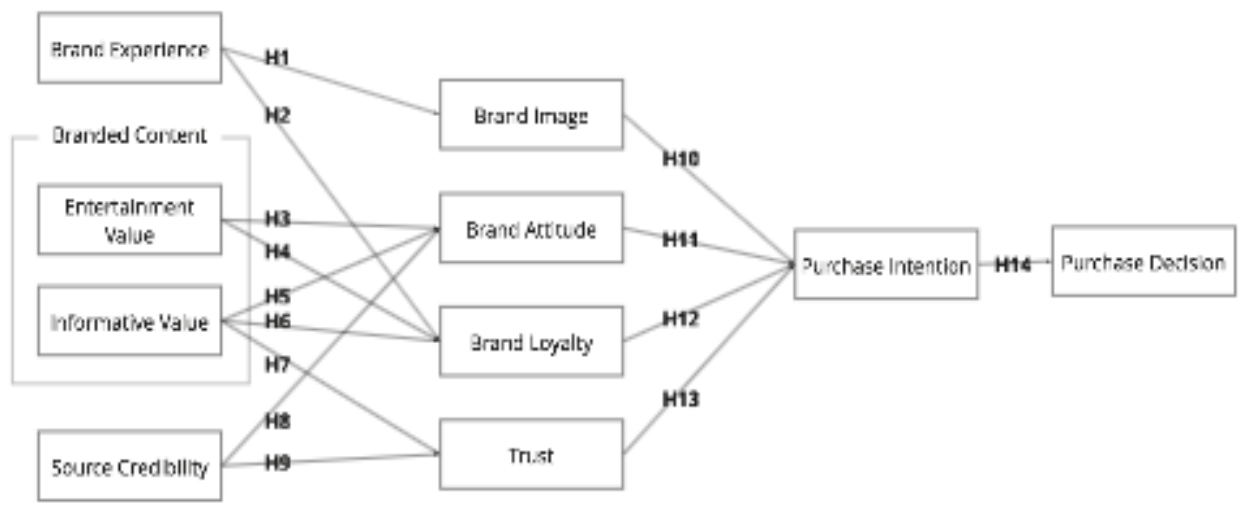

Figure 1. Conceptual Framework

Source: Author's Interpretation

From the conceptual framework above, we can conclude that the four independent variables that have been mentioned previously are the factors contained in a product placement content. These factors in this study are predicted to influence the purchase decision of the audience towards the products placed in the video. The above factors require a number of other variables, namely mediating variables such as Brand Image, Brand Attitude, Brand Loyalty, Trust, and Purchase Intention to influence the dependent variable, namely Purchase Decision. By analyzing the content of this product placement, it is hoped that later it will be known what are the factors that can effectively influence the audience to buy a product that is placed in the product placement content.

\section{Conclusion}

This study examines how respondents reacted to various criteria related to YouTube product placement in affecting their purchase decision. This research will be used and tested in future investigations based on the proposed conceptual model. The conceptual model will be tested quantitatively by distributing surveys and analyzing the results with statistical tests. This research will assist marketers in analyzing the impact of product placement variables on YouTube content on consumer purchase decisions and in developing a product placement strategy in YouTube content that is effective in influencing consumer purchase decisions. Another study on YouTube product placement could be compared to the findings of this study to gain a better understanding of consumer purchase decisions in Indonesia.

\section{Reference}

Aaker, D.A. (1991) Managing Brand Equity: Capitalizing on the Value of a Brand Name. New York: The Free Press.

A Content Analysis of Media Coverage of Female U . S . Senate Candidates from the South A Thesis Presented to the Graduate Faculty of the University of Louisiana at Lafayette In Partial Fulfillment of the Requirements for the Degree Master of Science Ange. (2016).

Agmeka, F., Wathoni, R. N., \& Santoso, A. S. (2019). The influence of discount framing towards brand reputation and brand image on purchase intention and actual behaviour in e-commerce. Procedia Computer Science, 161, 851-858. https://doi.org/10.1016/j.procs.2019.11.192

Anwar, I., \& Reham, K. U. (2013). FACTORS AFFECTING CONSUMER ATTITUDES USER-GENERATED PRODUCT CONTENT ON YOUTUBE Imran Anwar MIR 
Volume 3 Issue 9 (September 2021) PP. 143-154

Kashif Ur REHMAN. Management \& Marketing, 8(4), 637-654. http://search.proquest.com.ezproxy.library.uq.edu.au/docview/1503088220?pqorigsite $=$ summon

Apuke, O. D. (2017). Quantitative Research Methods : A Synopsis Approach. Kuwait Chapter of Arabian Journal of Business and Management Review, 6(11), 40-47. https://doi.org/10.12816/0040336

Aspers, P., \& Corte, U. (2019). What is Qualitative in Qualitative Research Content courtesy of Springer Nature, terms of use apply . Rights reserved . Content courtesy of Springer Nature , terms of use apply . Rights reserved . February, 139-160.

Asshidin, N. H. N., Abidin, N., \& Borhan, H. B. (2016). Perceived Quality and Emotional Value that Influence Consumer's Purchase Intention towards American and Local Products. Procedia Economics and Finance, 35(October 2015), 639-643. https://doi.org/10.1016/s2212-5671(16)00078-2

Aw, E. C. X., Chuah, S. H. W., Sabri, M. F., \& Kamal Basha, N. (2021). Go loud or go home? How power distance belief influences the effect of brand prominence on luxury goods purchase intention. Journal of Retailing and Consumer Services, 58(January). https://doi.org/10.1016/j.jretconser.2020.102288

Azaze-Azizi-Abbdul_Adis-.pdf. (n.d.).

Babacan, E., Akcali, S. İ., \& Baytekin, E. P. (2012). Product Placement as a Rising Marketing Communication Activity: An Assessment on Television Serials. Procedia - Social and Behavioral Sciences, 62(December 2011), 1319-1331. https://doi.org/10.1016/j.sbspro.2012.09.226

Baghi, I., \& Gabrielli, V. (2018). Brand prominence in cause-related marketing: luxury versus non-luxury. Journal of Product and Brand Management, 27(6), 716-731. https://doi.org/10.1108/JPBM-07-2017-1512

Bhattacherjee, A., \& Clive Sanford. (2016). Influence Processes for Information Technology Acceptance: An Elaboration Likelihood Model1. MIS Quarterly, 30(4), 805-825.

Boyd, D. E., Clarke, T. B., \& Spekman, R. E. (2014). The emergence and impact of consumer brand empowerment in online social networks: A proposed ontology. Journal of Brand Management, 21(6), 516-531. https://doi.org/10.1057/bm.2014.20

Brakus, J.J., Schmitt, B.H. and Zarantonello, L. (2009). Brand experience: What is it? How is it measured? Does it affect loyalty? Journal of Marketing 73(3): 52-68.

Bressoud, E., Lehu, J. M., \& Russell, C. A. (2010). The product well placed: The relative impact of placement and audience characteristics on placement recall. Journal of Advertising Research, 50(4). https://doi.org/10.2501/S0021849910091622

Canter, A., Asmussen, B., Michels, N., Butler, A., \& Thomson, S. (2013). Defining Branded Content for the Digital Age. Developing a clearer understanding of a 'new' key marketing concept. Retrieved from thebcma.info:http://www. thebcma.info/wpcontent/uploads/2016/07/BCMA-Research-Report_FINAL.pdf.

Cathcart, W. H., \& Killen, E. J. (1940). Scoring of Toast and Factors Which Affect Its Quality. Journal of Food Science, 5(3), 307-321. https://doi.org/10.1111/j.13652621.1940.tb17194.x

Chaipradermsak, T. (2007), "The influential factors on consumers' purchasing decision in Bangkok pet retailing business", MBA Thesis, Shinawatra University.

Choi, D., Bang, H., Wojdynski, B. W., Lee, Y. I., \& Keib, K. M. (2018). How Brand Disclosure Timing and Brand Prominence Influence Consumer's Intention to Share Branded Entertainment Content. Journal of Interactive Marketing, 42(May), 18-31. https://doi.org/10.1016/j.intmar.2017.11.001 
Volume 3 Issue 9 (September 2021) PP. 143-154 DOI 10.35631/AIJBES.39011

Christensson, P. (2009). YouTube Definition. Retrieved from techterms.com: https://techterms.com/definition/youtube

Cokki, C., Soelaiman, L., \& Puspitowati, I. (2019). Transformasi Digital Merek-Merek Indonesia Dalam Bentuk Penempatan Produk Pada Web Series Di Situs Web Youtube [Digital Transformation of Indonesian Brands in the Form of Product Placement on Web Series on the Youtube Website]. DeReMa (Development Research of Management): Jurnal Manajemen, 155. https://doi.org/10.19166/derema.v14i1.1305

Costa-Sánchez, C. (2017). Use of YouTube for Business Communication. Analysis of the Content Management and Level of Participation of Spanish Best Reputed Companies Youtube Channels. Corporate Reputation Review, 20(2), 137-146. https://doi.org/10.1057/s41299-017-0021-8

Dachyar, M., \& Banjarnahor, L. (2017). Factors influencing purchase intention towards. Intangible Capital, 13(5), 946-966.

Dahlén, M., \& Lange, F. (2005). Advertising weak and strong brands: Who gains? Psychology and Marketing, 22(6), 473-488. https://doi.org/10.1002/mar.20069

Datareportal. (2019). Global Digital Overview. Retrieved from datareportal.com: https://datareportal.com/reports/digital-2019-global-digital-overview

Delgado-Ballester, E. and Munuera-Aleman, J.L. (2001). Brand trust in the context of consumer loyalty. European Journal of Marketing, 12(12): 1238-1258.

Delgado-Ballester, E. (2004). Applicability of a brand trust scale across product categories. European Journal of Marketing, 38(5/6), 573-592. https://doi.org/10.1108/03090560410529222

Domínguez-Navarro, S., \& González-Rodríguez, M. R. (2020). Social Media managerial implications for budget accommodation venues: use of Social Media platforms more effectively and efficiently. Quality and Quantity, 54(5-6), 1671-1689. https://doi.org/10.1007/s11135-019-00932-3

Ducoffe, R.H. (1996), “Advertising value and advertising on the web”, Journal of Advertising Research, Vol. 36 No. 5, pp. 21-21.

Eagle, L., \& Dahl, S. (2018). Product Placement in Old and New Media: Examining the Evidence for Concern. Journal of Business Ethics, 147(3), 605-618. https://doi.org/10.1007/s10551-015-2955-z

Eagly, A.H. and Chaiken, S. (1993), The Psychology of Attitudes, Harcourt Brace Jovanovich, Fort Worth, TX.

Folkvord, F., Bevelander, K. E., Rozendaal, E., \& Hermans, R. (2019). Children's bonding with popular YouTube vloggers and their attitudes toward brand and product endorsements in vlogs: an explorative study. Young Consumers, 20(2), 77-90. https://doi.org/10.1108/YC-12-2018-0896

Fournier, Susan (1998), "Consumers and Their Brands: Developing Relationship Theory in Consumer Research,” Journal of Consumer Research, 24(3), 343-53.

Gerhards, C. (2019). Product placement on YouTube: An explorative study on YouTube creators' experiences with advertisers. Convergence, 25(3), 516-533. https://doi.org/10.1177/1354856517736977

Goldsmith, R. E., Flynn, L. R., Stacey, E. C., \& Partners, M. (2020). BRAND ATTITUDES AND BRAND COMMITMENT. January 2009.

Guennemann, F., \& Cho, Y. C. (2014). And Intention To Purchase. 7(1).

Hanaysha, J. R. (2018). An examination of the factors affecting consumer's purchase decision in the Malaysian retail market. PSU Research Review, 2(1), 7-23. https://doi.org/10.1108/prr-08-2017-0034

Copyright $\odot$ GLOBAL ACADEMIC EXCELLENCE (M) SDN BHD - All rights reserved 
Volume 3 Issue 9 (September 2021) PP. 143-154 DOI 10.35631/AIJBES.39011

Haque, A., Anwar, N., Yasmin, F., Sarwar, A., Ibrahim, Z., \& Momen, A. (2015). Purchase intention of foreign products: A study on Bangladeshi consumer perspective. SAGE Open, 5(2), 1-12. https://doi.org/10.1177/2158244015592680

HIDALGO-MARÍ, T., \& SEGARRA-SAAVEDRA, J. (2017). The YouTube influencer phenomenon and its transmedia expansion. Analysis of youth empowerment in social media. Fonseca, Journal of Communication, 15(15), 43.

Hou, C., \& Wonglorsaichon, P. (2016). the Relationship Among Brand Awareness, Brand Image, Perceived Quality, Brand Trust, Brand Loyalty and Brand Equity of Customer in China'S Antivirus Software Industry. UTCC International Journal of Business \& Economics, 8(1), 153-170. http://escweb.lib.cbs.dk/login?url=http://search.ebscohost.com/login.aspx?direct=true $\& \mathrm{db}=\mathrm{bth}$ $\& \mathrm{AN}=116484624 \&$ site $=$ ehost-live $\&$ scope $=$ site

Hypeauditor. (2021). Top 1000 YouTube Channels in Indonesia. Retrieved from hypeauditor.com: https://hypeauditor.com/top-youtube-all-indonesia/

IPG Medial Lab. (2015). IPG Lab + google release deconstructing branded content: The global guide to what works. Retrieved from ipglab.com: https://www.ipglab.com/wpcontent/uploads/2015/11/ipg-lab-google-global-branded-content-finalexternal_flattened_reducedsize.pdf

Jacoby, J. and Kyner, D.B. (1973), "Brand loyalty versus repeat purchasing behavior", Journal of Marketing Research, Vol. 10, pp. 1-9.

Jin, S. V., \& Muqaddam, A. (2019). Product placement 2.0: "Do Brands Need Influencers, or Do Influencers Need Brands?" Journal of Brand Management, 26(5), 522-537. https://doi.org/10.1057/s41262-019-00151-z

Justine, A. (2020). YouTube Statistics: A Look at Its Effect on YouTube's Digital Marketing. Jusufovic-Karisik, V. (2014). 20 Years of Research on Product Placement in Movie, Television and Video Game Media. Journal of Economic and Social Studies, 4(2), 98-108. https://doi.org/10.14706/jecoss114210

Karrh, J. A. (1998). Brand Placement: A Review. Journal of Current Issues \& Research in Advertising, 20(2), 31-49. doi:10.1080/10641734.1998.10505081

Keller, K.L. (1993). Conceptualizing, measuring, and managing customer-based brand equity, Journal of Marketing, Vol. 57 No. 1, pp. 1-22.

Keller, K. L. (2001). Building customer-based brand equity: creating brand resonance requires carefully sequenced brand-building efforts, Marketing Management, Vol. 10, No. 2, pp. 15-19.

Keller, K.L. and Lehmann, D.R. (2006). Brands and branding: research findings and future priorities, Marketing Science, Vol. 25 No. 6, pp. 740-759.

Khurram, M., Qadeer, F., \& Sheeraz, M. (2018). The Role of Brand Recall, Brand Recognition and Price Consciousness in Understanding Actual Purchase. Journal of Research in Social Sciences, 6(2), 219-241.

Kim, R. B., \& Chao, Y. (2019). Effects of brand experience, brand image and brand trust on brand building process: The case of chinese millennial generation consumers. Journal of International Studies, 12(3), 9-21. https://doi.org/10.14254/2071-8330.2019/12-3/1

Klobas, J. E., McGill, T. J., Moghavvemi, S., \& Paramanathan, T. (2019). Problematic and extensive YouTube use: first hand reports. Online Information Review, 43(2), 265-282. https://doi.org/10.1108/OIR-01-2018-0032

Komposisi, K. D. A. N. (2012). Karakteristik dan komposisi. 1-11.

Kramolis, J., \& Kopeckova, M. (2013). Product Placement: A Smart Marketing Tool Shifting a Company to the Next Competitive Level. Journal of Competitiveness, 5(4), 98-114. https://doi.org/10.7441/joc.2013.04.06

Copyright $\odot$ GLOBAL ACADEMIC EXCELLENCE (M) SDN BHD - All rights reserved 
Volume 3 Issue 9 (September 2021) PP. 143-154 DOI 10.35631/AIJBES.39011

Kristanto, H., \& Karina M.R. Brahmana, R. (2016). Pengaruh Product Placement Pada Film Indonesia Terhadap Brand Awareness Dan Purchase Intention Masyarakat Surabaya. Jurnal Manajemen Pemasaran, 10(1). https://doi.org/10.9744/pemasaran.10.1.20-26

Kristanto, H., \& Karina M.R. Brahmana, R. (2016). Pengaruh Product Placement Pada Film Indonesia Terhadap Brand Awareness Dan Purchase Intention Masyarakat Surabaya. Jurnal Manajemen Pemasaran, 10(1), 20-26. https://doi.org/10.9744/pemasaran.10.1.20-26

Lai, M., \& Huang, Y.-S. (2011). Can learning theoretical approaches illuminate the ways in which advertising games effect attitude, recall, and purchase intention. International Journal of Electronic Business Management, 9(4), 368-380. http://search.ebscohost.com/login.aspx?direct=true $\& d b=b t h \& A N=70423262 \&$ site $=b s$ i-live

Lee, J. E., \& Watkins, B. (2016). YouTube vloggers' influence on consumer luxury brand perceptions and intentions. Journal of Business Research, 69(12), 5753-5760. https://doi.org/10.1016/j.jbusres.2016.04.171

Lee, J. E., \& Watkins, B. (2016). YouTube vloggers' influence on consumer luxury brand perceptions and intentions. Journal of Business Research, 69(12), 5753-5760. https://doi.org/10.1016/j.jbusres.2016.04.171

Liu, S. H., Chou, C. H., \& Liao, H. L. (2015). An exploratory study of product placement in social media. Internet Research, 25(2), 300-316. https://doi.org/10.1108/IntR-12-20130267

Lou, C., Xie, Q., Feng, Y., \& Kim, W. (2019). Does non-hard-sell content really work? Leveraging the value of branded content marketing in brand building. Journal of Product and Brand Management, 28(7), 773-786. https://doi.org/10.1108/JPBM-072018-1948

Malhotra, N. K., Nunan, D., \& Birks, D. F. (2016). Marketing research. In The Marketing Book: Seventh Edition. https://doi.org/10.4324/9781315890005

Matzler, K., Grabner-Kräuter, S. and Bidmon, S. (2008), "Risk aversion and Brand loyalty: the mediating role of Brand trust and Brand affect", Journal of Product \& Brand Management, Vol. 17No. 3, pp. 154-162.

Mayer, A., Thoemmes, F., Rose, N., Steyer, R., \& West, S. G. (2014). Theory and Analysis of Total, Direct, and Indirect Causal Effects. Multivariate Behavioral Research, 49(5), 425-442. https://doi.org/10.1080/00273171.2014.931797

McQuail, D. (1983), Mass Communication Theory: An Introduction, Sage, London

Muntinga, D.G., Moorman, M. and Smit, E.G. (2011), "Introducing COBRAs: exploring motivations for Brand-related social media use", International Journal of Advertising, Vol. 30No. 1, pp. 13-46.

Navarro-Rivera, J., \& Kosmin, B. A. (2013). Surveys and questionnaires. The Routledge Handbook of Research Methods in the Study of Religion, 395-420. https://doi.org/10.4324/9780203154281-35

Nayeem, T., Murshed, F., \& Dwivedi, A. (2019). Brand experience and brand attitude: examining a credibility-based mechanism. Marketing Intelligence and Planning, 37(7), 821-836. https://doi.org/10.1108/MIP-11-2018-0544

Newell, J., Salmon, C. T., \& Chang, S. (2006). The Hidden History of Product Placement. Journal of Broadcasting \& Electronic Media, 50(4), 575-594. https://doi.org/10.1207/s15506878jobem5004_1

Panda, T.K. (2004). Consumer Response to Brand Placements in Films Role of Brand Congruity and Modality of Presentation in Bringing Attitudinal Change Among 
Volume 3 Issue 9 (September 2021) PP. 143-154 DOI 10.35631/AIJBES.39011

Consumers with Special Reference to Brand Placements in Hindi Films. South Asian Journal of Management, New Delhi, 11(4), October-December, 7-26.

Park, C.W. and MacInnis, D.J. (2006), "What's in and what's out: questions on the boundaries of the attitude construct", Journal of Consumer Research, Vol. 33 No. 1, pp. 16-18

Pars, S. R., \& Gulsel, C. (2011). The effects of brand image on consumers' choice. International Journal of Business and Social Science, 2(20), 227-238

Peña-García, N., Gil-Saura, I., Rodríguez-Orejuela, A., \& Siqueira-Junior, J. R. (2020). Purchase intention and purchase behavior online: A cross-cultural approach. Heliyon, 6(6). https://doi.org/10.1016/j.heliyon.2020.e04284

Pirouz, D. M. (2012). An Overview of Partial Least Squares. SSRN Electronic Journal, October 2006. https://doi.org/10.2139/ssrn.1631359

Pollay, R. \& Mittal, B. (1993) Here's the heef: factors, determinants, and segments in consumer criticism of advertising. Journal of Marketing, 57(3), 99-114.

Praditya, D. (2018). 3 Fakta Menarik dari Riset Google tentang Perkebangan YouTube di Indonesia. Retrieved from id.techinasia.com: https://id.techinasia.com/faktaperkembangan-youtube-di-indonesia

Ramaseshan, B., \& Stein, A. (2014). Connecting the dots between brand experience and brand loyalty: The mediating role of brand personality and brand relationships. Journal of Brand Management, 21(7), 664-683. https://doi.org/10.1057/bm.2014.23

Rose, J., Cho, E., \& Smith, K. R. (2016). The Effects of Brand Familiarity on Perceived Risks, Attitudes, and Purchase Intentions toward Intimate Apparel Brand. International Textile and Apparel Association, November, 24-26.

Russell, C. A. (1988). Toward a framework of product placement. Advances in Consumer Research, XXV(January 1998), 357-362. http://www.acrwebsite.org/volumes/display.asp?id=8178

Russell, C. A. (2002). Investigating the Effectiveness of Product Placements in Television Shows: The Role of Modality and Plot Connection Congruence on Brand Memory and Attitude. Journal of Consumer Research, 29(3), 306-318. https://doi.org/10.1086/344432

Sallam, M. A., \& Algammash, F. A. (2016). The effect of Attitude toward Advertisement on Attitude toward Brand and Purchase Intention. International Journal of Economics, Commerce and Management United Kingdom, 4(2), 21-29. http://ijecm.co.uk/

Sarstedt, M., Ringle, C. M., \& Hair, J. F. (2020). Handbook of Market Research. In Handbook of Market Research (Issue September). https://doi.org/10.1007/978-3-319-05542-8

Satish, J. And Peter, K. (2004). Customer Response Capability in a Sense-And-Respond Era The role of customer knowledge process. J. Acad. Mark. Sci., 32 (3): 219-233.

Schiffman, L.G. and Kanuk, L.L. (2007), Consumer Behavior, 9th ed., Prentice-Hall, NJ.

Sel, H. F. Y. (2016). Factors Affecting Purchase Intention in Youtube Videos. Youtube Videolarinda Satin AlNiyetiniEtkileyen Faktörler., 11(2), 33-47. http://0search.ebscohost.com.lib.utep.edu/login.aspx?direct=true \&db=a9h\&AN=126227094 \&site $=$ ehost-live \&scope $=$ site

South, R., Journal, A., \& Collection, I. (2009). Marketing accountability: how to measure marketing effectiveness. Choice Reviews Online, 47(04), 47-2096-47-2096. https://doi.org/10.5860/choice.47-2096

Statista. (2019). Penetration of Leading Social Networks in Indonesia as of 3rd quarter 2019. Retrieved from statista.com: https://www.statista.com/statistics/284437/indonesiasocial-network- penetration/

Stubb, C., Nyström, A. G., \& Colliander, J. (2019). Influencer marketing: The impact of disclosing sponsorship compensation justification on sponsored content effectiveness. 
Volume 3 Issue 9 (September 2021) PP. 143-154 DOI 10.35631/AIJBES.39011

Journal of Communication Management, 23(2), 109-122. https://doi.org/10.1108/JCOM-11-2018-0119

Świtała, M., Gamrot, W., Reformat, B., \& Bilińska-Reformat, K. (2018). The influence of brand awareness and brand imageon brand equity - an empirical study of logisticsservice providers. Journal of Economics and Management, 33(3), 96-119. https://doi.org/10.22367/jem.2018.33.06

Taherdoost, H. (2018). Validity and Reliability of the Research Instrument; How to Test the Validation of a Questionnaire/Survey in a Research. SSRN Electronic Journal, September. https://doi.org/10.2139/ssrn.3205040

The_Effectiveness_of_Implicit_.pdf. (n.d.).

Ur Rehman, H. I., \& Ishaq, Z. (2017). The Impact of Brand Image on Purchase Intention: Moderating Role of Store Image in Pakistan's Retail Sector. The IUP Journal of Brand Management, 14(3), 54-66.

Vannucci, A., \& McCauley Ohannessian, C. (2019). Social Media Use Subgroups Differentially Predict Psychosocial Well-Being During Early Adolescence. Journal of Youth and Adolescence, 48(8), 1469-1493. https://doi.org/10.1007/s10964-01901060-9

Vashisht, D., \& S. Pillai, S. (2017). Are you able to recall the brand? The impact of brand prominence, game involvement and persuasion knowledge in online - advergames. Journal of Product and Brand Management, 26(4), 402-414. https://doi.org/10.1108/JPBM-02-2015-0811

Vashist, D. (2018). Effect of product involvement and brand prominence on advergamers' brand recall and brand attitude in an emerging market context. Asia Pacific Journal of Marketing and Logistics, 30(1), 43-61. https://doi.org/10.1108/APJML-01-2016-0014

Verhellen, Y., Dens, N., \& Pelsmacker, P. D. (2013). Consumer Responses To Brands Placed in Youtube Movies : the. In Journal of Electronic Commerce Research (Vol. 14, Issue 4, pp. 287-303).

Whiting, A., \& Williams, D. (2013). Why people use social media: a uses and gratifications approach. Qualitative Market Research: An International Journal, 16(4), 362-369. https://doi.org/10.1108/QMR-06-2013-0041

Williams, K., \& Petrosky, A. (2011). Product placement effectiveness: revisited and renewed. Journal of Management \& Marketing Research, 6491(May), 1-24. http://search.ebscohost.com/login.aspx?direct=true \&profile=ehost\&scope=site\&autht ype $=$ crawler $\& j \mathrm{rnl}=19413408 \& A N=59782912 \& \mathrm{~h}=\mathrm{yQG}$ 4Wqx4Ds4LC437RwQTcI68 DeJt+aPkRkdZ+N9tqXsV5PLQ8pKH6Sivt1TQ33ORIBygRFa8cVqmSeFS0OkAnQ $==\& \mathrm{crl}=\mathrm{c}$

Y. Wang, S. Wu, H. Lin, and Y. Wang. (2011). "The Relationship of Service Failure Severity, Service Recovery Justice, and Perceived Switching Costs with Customer Loyalty in the Context of e-tailing," International Journal of Information Management, 31, 350-359

Young, J. H., Nunes, J. C., \& Drèze, X. (2010). Signaling status with luxury goods: The role of brand prominence. Journal of Marketing, 74(4), 15-30. https://doi.org/10.1509/jmkg.74.4.15 